\title{
CLERGUES “FEUDATARIS". \\ LA DISGREGACIÓ DEL PATRIMONI DE LA SEU DE BARCELONA I ELS ORÍGENS DEL SISTEMA BENEFICIAL \\ $(1091-1157)^{\prime}$
}

\author{
PERE BENITO I MONCLÚS \\ Institució Milà $i$ Fontanals \\ (CSIC, Barcelona)
}

\begin{abstract}
SUMARI
1. Introducció.- 2. Clergues "feudataris".- 3. El domini capitular: canonges i familiars.- 4. Els orígens de la mensa episcopal.- 5. La hipòtesi d'una crisi del domini.
\end{abstract}

\section{INTRODUCCIÓ}

A començaments del segle XI l'església de Barcelona es trobava al front d'un dels dominis territorials més extensos de la Catalunya comtal. El patrimoni de la seu de Barcelona, integrat per béns d'origen fiscal i per les aprisions dels territoris de la Marca, hauria assolit la seva màxima expansió a la segona meitat del segle $\mathrm{X}$, com a conseqüència de les importants

\footnotetext{
'A la memòria de la Regina, amb qui tantes bones estones vaig compartir durant la meva recerca de doctorat a l'Arxiu de la Corona d'Aragó.

Abreviatures emprades: $\mathrm{ACB}=$ Arxiu Capitular de Barcelona; $\mathrm{ADB}=$ Arxiu Diocesà de Barcelona; $L A=$ Libri Antiquitatum.

"Anuario de Estudios Medievales". 29 (1999)
} 
donacions del comte Miró (966) i del bisbe Vives (995), i d'una adequada política d'adquisició de propietats a l'hinterland barceloní2.

Segons Gaspar Feliu la restauració i dotació de la canònica de Barcelona al final de l'episcopat d'Aeci (1009) fou el punt de partida de la constitució d'un patrimoni de la canònica diferenciat del de la seu. Per les mateixes dates s'hauria produit la fundació d'un hospital per a pobres i peregrins, dependent de la sagristia de la catedral, origen de la Pia Almoina posterior ${ }^{3}$. A partir d'aleshores el domini de la seu quedava escindit en tres unitats diferents: els béns i rendes del bisbe, els del capítol i els de l'hospital.

Fins a finals del segle XI el temporal de l'església de Barcelona i de les institucions nascudes a redós seu fou gestionat de manera unitària. A partir del darrer decenni del segle XI, però, dos canvis importants assenyalen un tombant en la història de la institució: d'una banda, l'esclat de la gestió integrada del domini ${ }^{4}$, que culminà amb la institucionalització del sistema

\footnotetext{
${ }^{2}$ El procés de formació del domini de la seu de Barcelona en el seu primer segle i mig d'història documentada, entre el precepte de Carles el Calb de 860-862 i el final del pontificat d'Aeci (1010), fou l'objecte de la tesi doctoral de Gaspar FELIU I MONFORT, El dominio territorial de la Sede de Barcelona (800-1010), Universitat de Barcelona, 1971, 3 vols, publicada a: La formación del dominio territorial de la sede de Barcelona (800-1010), "Cuadernos de Historia Económica de Cataluña" (1972), pp. 9-32; Els inicis del domini territorial de la Seu de Barcelona, "Cuadernos de Historia Económica de Cataluña", XIV (marc 1976), pp. 45-61; El bisbe Vives de Barcelona i el patrimoni de la Catedral (974-995). "Miquel Coll i Alentorn. Miscel-lània d'homenatge en el seu vuitantè aniversari", Barcelona, Fundació Jaume I, 1984, pp. 167-191; El patrimoni de la seu de Barcelona durant el pontificat del bisbe Aeci (995-1010), "Miscel-lània Ramon d'Abadal. Estudis d'història oferts a Ramon d'Abadal i de Vinyals en el centenari del seu naixement”, Barcelona, Estudis Universitaris Catalans, 1994, pp. 51-68.

${ }^{3}$ L'any 1009 el bisbe Aeci cedí a la congregació de canonges l'església de Santa Maria del Mar, el claustre tocant a la seu, un edifici inacabat destinat a refetor, un espai destinat a la construcció de cases per als canonges i diversos drets i rendes sobre els castells i les terres artigades de l'altre costat del Llobregat, als quals afegiria més tard l'església de Sant Joan Despí. Els comtes Ramon Borrell i Ermessenda, per la seva banda, es comprometeren a llliurar certa quantitat d'or. La comunitat, solemnement erigida en canònica el mes de març d'aquell mateix any, obtingué el dret a elegir abat, prepòsits, degans i ministres per al seu regiment $\mathrm{i}$ administració. FELIU, El dominio territorial, pp. 153 i 161-165; El patrimoni de la seu de Barcelona durant el pontificat de bisbe Aeci (995-1010), pp. 51-52.

${ }^{4}$ Fenomen ja assenyalat per Roland Viader en el seu estudi sobre la documentació contractual de l'Arxiu Capitular. Segons aquest autor moltes de les cessions a cens d'aquesta època tindrien com a funció fixar jurídicament les relacions entre la institució, representada pel bisbe, i una elit d'eclesiàstics als quals hom delegava la gestió de parts del domini capitular. Roland VIADER, Les contrats agraires des archives capitulaires de Barcelone (XI'-XIII' siècle), "Mémoire de maîtrise" inèdit, Université de Toulouse-Le Mirail, 1990; Autour d'une pratique juridique: les contrats agraires des archives capitulaires de Barcelone (XI'-XIII" siècle), "Acta Historica et Archaeologica Mediaevalia”, 16-17 (1995-1996), pp. 147-165.
} 
beneficial a mitjan segle XII i, en relació estreta amb aquest procés, la configuració de patrimonis independents vinculats a la canònica i a les funcions del bisbe i de l'ardiaca de la seu. Presentem aquí una primera aproximació a aquests dos processos a partir de la hipòtesi que existí una relació estreta entre els canvis que afectaren la institució en aquest període i l'evolució del domini'.

\section{Clergues “Feudataris"}

Fins al darrer decenni del segle XI el domini de la seu de Barcelona es mantingué de manera unitària sota el control del bisbe o dels seus delegats. Els contractes eren atorgats pel bisbe que, segons les fòrmules emprades, actuava sempre conjuntament i de mutu acord amb la congregació de canonges que li eren subjectes ${ }^{6}$, o excepcionalment pel bisbe i l'ardiaca de la seu $(1061,1068)^{7}$. Una única vegada figura el levita Guerau, arxiver (archiscrinius) de la seu, atorgant un contracte de precària $(1054)^{8}$.

A partir de 1072 la gestió i administració del patrimoni de la catedral és delegada, en moments diferents, a dues figures: el sacricustos, l'encarregat de l'administració del temporal, que actua, en algunes concessions, sol o fent costat al bisbe $(1072,1073,1074$ i 1082) i el prepòsit de la seu (1072, 1074).

\footnotetext{
${ }^{5}$ Hem consultat la documentació copiada als Libri Antiquitatum i la documentació original en pergamí de les sèries $\mathrm{A}, \mathrm{B}$ i $\mathrm{C}(\mathrm{b}, \mathrm{c} \mathrm{i}$ d) del fons Diversorum de l'Arxiu Capitular de Barcelona. Els $L A$ i els pergamins de les sèries Diversorum són encara avui, mercès al treball de catalogació que $\mathrm{Mn}$. Josep Mas dugué a terme mentre era arxiver de la catedral, els dos grans conjunts de documentació de l'Arxiu Capitular en condicions òptimes d'accessibilitat i de consulta. Els regestos dels documents dels $L A$ foren publicats per Mn Josep MAS, Notes històriques del bisbat de Barcelona, vols. IX-XII (Rubrica dels Libri Antiquitatum de la Sèu de Barcelona), Barcelona, 1914-1915. Sobre l'origen i la composició del fons Diversorum, vegeu Josep BAuCElls I Reig, El Baix Llobregat i la Pia Almoina de la Seu de Barcelona: inventari de pergamins, Barcelona, Departament de Cultura de la Generalitat de Catalunya, 1984, pp. 1923 .

${ }^{6} \mathrm{D}$ 'acord amb una fòrmula que perviu fins ben entrat el segle XII. 1160: "Sit notum cunctis quod ego Guillelmus, Dei gratia Barchinonensis episcopus, et canonicorum conventus mihi subditus damus tibi...”. ACB, $L A$, I, f. $231 \mathrm{r}-\mathrm{v}$, doc. 625 (còpia del segle XIII).

${ }^{7} \mathrm{ACB}, L A$, II, f. $27 \mathrm{r}-\mathrm{v}$, d. 78 (còpia del segle XIII); 1-2-720 (orig.), $L A$, II, f. 18r, doc. 49 (còpia del s. XIII).

${ }^{8} \mathrm{ACB}, L A$, II, f. $148 \mathrm{r}-\mathrm{v}$, d. 432 (còpia del s. XIII).
} 
Aquesta situació canvia radicalment el darrer decenni del segle XI. A partir de 1091, a més del prepòsit de la seu, que actua com a delegat del bisbe en la gestió del patrimoni, apareixen, com a atorgants de contractes, canonges o clergues vinculats a la seu que declaren tenir els béns que cedeixen en feu per l'església o la canònica de Barcelona. Aquests detentors de feus de la catedral intengren un clercle reduït d'eclesiàstics que s'interposen entre la institució i els seus tinents; de fet, substitueixen el bisbe en la gestió de porcions més o menys grans del domini de la seu.

Veiem-ne alguns exemples. L'any 1094 el canonge Esteve Adalbert cedeix a Company Bonhome, per a complantar vinya, dues mujades de terra que té a Monterols en feu de la seu de Barcelona ${ }^{9}$. L'any 1096 Guillem Ramon $^{10}$ cedeix a Ramon Gerbert i a la femina Adelaida, als seus fills $\mathrm{i}$ descendents, una peça de terra situada a la parròquia de Sant Boi, al Casal de Joan, del feu que té pel sacricustos de la seu de Barcelona" ${ }^{11}$. Pere Umbert l'any 1098 cedeix a Tedbal, fill de Dalmau, i als seus fills i descendents, el mas que fou de Jofre Florit, situat al terme del castell de Rubí, sota la buada, que "té en feu per la canònica de la seu de Barcelona" ${ }^{\prime 2}$. Entre 1100 i 1107, el bisbe Berenguer cedeix a la canònica una part del seu episcopatus, unes cases tocant a l'església de Sant Miquel, que eren tingudes per Ramon Dalmau, degà de la canònica, per episcopalem fevum ${ }^{13}$. L'any 1110 el levita Alamany Hug cedeix a Bernat Guillem i a la seva muller, la femina Ermessenda, una terra amb rovira situada al terme de Sentmenat, al lloc Cuiars, que té "per l'església de Sant Miquel i pel feu que té per la canònica de la seu de Barcelona"14.

\footnotetext{
${ }^{9} \mathrm{ACB}, L A$, I, f. $106 \mathrm{v}-107 \mathrm{r}$, doc. 260. Joan

${ }^{10}$ Possiblement, es tracta de Guillem Ramon, cap d'escola, fill del cap d'escola Ramon 1183).

"ACB, $L A, \mathrm{I}$, f. $201 \mathrm{r}-\mathrm{v}$, d. 542 (còpia del segle XIII d'una còpia del 8 de desembre del

${ }^{12} \mathrm{ACB}, L A$, IV, f. 72 r, d. 200 (còpia del segle XIII).

${ }^{13} \mathrm{ACB}, 1-2-717$, sense data. Gaspar Feliu, "Història de Barcelona", 2, pp. 223 i 261, cita aquest document com un dels primers exemples de feu eclesiàstic, però el data erròniament entre 1063-1069 en època del bisbe Berenguer. La datació durant l'episcopat del segon Berenguer. entre 1100 i 1107, ens sembla més coherent amb l'aparició documental dels feus eclesiàstics.

${ }^{14} \mathrm{ACB}, L A$, III, f. $111 \mathrm{v}$, d. 292 (còpia del segle XIII).
} 
En aquestes concessions el mot feu implica dues coses: la capacitat de gestionar els béns i la facultat de percebre'n les rendes (l'usdefruit) ${ }^{15}$.

En aquest moment es donen de manera paral-lela quatre fenomens estretament relacionats $\mathrm{i}$ no sempre diferenciables: a) alguns eclesiàstics vinculats a la seu apareixen com a gestors de béns que usufructuen o "tenen en feu" per la seu o la canònica; b) alguns béns son associats al càrrec o la funció que el clergue exerceix en el marc de la institució; c) alguns béns oscil·len entre el patrimoni de la institució i el de la família del clergue beneficiari; d) alguns càrrecs o funcions eclesiàstiques tendeixen a ésser patrimonialitzats, essent objecte de transmissió hereditària en el si de determinades famílies. D'acord amb la hipòtesi que defensem, el naixement del sistema beneficial estaria, per tant, estretament relacionat amb els orígens d'una gestió autònoma dels patrimonis de les grans institucions nescudes a redòs de l'església de Barcelona, l'hospital i, de manera particular, la canònica de la seu.

Els primers exemples d'una gestió autònoma, conduïda individualment pels canonges, concerneixen els béns de l'hospital de la seu. Tot i que, tal i com establí Feliu, l'existència d'un patrimoni de l'hospital, diferenciat de la seu, data des de la seva mateixa fundació a començaments del segle $\mathrm{XI}^{16}$, les primeres traces de la gestió d'aquests béns es vinculen a la figura del canonge Miró Goltred, que l'any 1090, a través del seu nebot, el canonge Miró Balloví, féu donació a l'hospital de tot el seu alou de Reixac ${ }^{17}$; uns mesos més tard, l'any 1091 , actuava com a virtual rectoradministrador d'aquesta institució en cedir un peça de terra que tenia "per

\footnotetext{
${ }^{15}$ Estem lluny, per tant, del sentit clàssic del mot feu. El feu entès com a usdefruit i benefici, desprovist de la fidelitat $\mathrm{i}$ del vassallatge, es troba a Occitània a partir del segle XI. Elisabeth MAGNOU-NORTIER, La terre, la rente et le pouvoir dans les pays du Languedoc pendant le Haut Moyen Age(III), "Francia", t. 12 (1984), pp. 74-94, en contra de tota la historiografia del dret, el considera una pervivència fiscal. Per a Paul OuRliaC, "A feo dare". note sur le fief toulousain aux X' et XI' siècles, "Homenaje a Don Claudio Sánchez Albornoz", t. II, Buenos Aires, 1983, "Les pays de Garonne vers l'an mil. La société et le droit", Tolosa de Llenguadoc, 1993, pp. 79-88, Propriété et féodalité en Rouergue, "Les pays de Garonne...", pp. 147-154, es tracta d'una institució privada que implica benefici. Gaspar FELIU I MONFORT, Activitats econòmiques, "Història de Barcelona", vol. 2. ("La formació de la Barcelona medieval"), Barcelona, Ajuntament de Barcelona - Fundació Enciclopèdia Catalana, 1992, pp. 209-270, considera el feu eclesiàstic, al costat de l'emfiteusi, com una figura més de gestió del domini de la seu de Barcelona.

${ }^{16} \mathrm{FELIU}$, El patrimoni de la seu de Barcelona durant el pontificat del bisbe Aeci (995-1010), pp. 67-68.

${ }^{17}$ Miró Balloví actua a precs del seu oncle Miró Goltred. ACB, LA, I, f. 299r-v, doc. 824.
} 
dret de l'hospital de Santa Creu i Santa Eulàlia de Barcelona" 18. L'any 1098 el seu nebot, Miró Balloví, cedia una peça de terra que tenia "per la donació que li féu el seu oncle i per l'hospital de la seu"; els receptors haurien de lliurar la quarta part, el delme, la primícia i el braçatge de tots els fruits a l'atorgant mentre visqués $i$, un cop mort, a l'hospital ${ }^{19}$. A partir de la dècada de 1120 al front de la gestió dels béns de l'hospital trobem ja institucionalitzat el càrrec de rector-administrador (custos), que l'any 1122 recau en la persona del clergue Ponç ${ }^{20}$ i entre 1152 i 1154 en la figura del prevere Ademar ${ }^{21}$.

Al llarg del segle XI es constituí un patrimoni propi de la canònica de Barcelona, principalment a partir de les oblacions efectuades per famílies amb propietats a l'hinterland barceloní ${ }^{22}$. El domini de la canònica, essencialment periurbà, fou confirmat l'any 1104 pel papa Pasqual II al bisbe Ramon i al capítol de canonges de la $\operatorname{seu}^{23}$. Entorn d'aquesta data trobem els primers exemples de concessions de béns de la canònica efectuades pel capítol de canonges de la seu al marge de l'autoritat de l'ordinari ${ }^{24}$.

\footnotetext{
${ }^{18}$ Miró Goltred cedeix a Joan Miró, a la seva muller Domènega, femina, i als seus fills i descendents per a complantar vinya tres quarterades de terra, situades al terme de Monterols. Joan Miró i els seus descendents lliuraran cada any el quart el delme de la verema a l'hospital. ACB, 1-2-1225; LA, I, f. 300v, doc. 829 (còpia del s. XIII).

${ }^{19} \mathrm{~A}$ ixò no vol dir, però, necessàriament que Miró Balloví actués com a usufructuari d'aquest béns, puix que més endavant hom estableix que els receptors no faran cap altre senyor que no sigui el donador o aquells que tinguessin l'hospital després del seu òbit; hom pot interpretar que Miró Balloví actuava, com el seu oncle, en qualitat de rector-administrador de l'hospital. ACB, $L A$, I, f. 140v, doc. 362 (còpia del s. XIII).

${ }^{20}$ Ponç, amb l'aprobació de l'arquebisbe Oleguer i dels canonges de la seu, cedeix al canonge Reguer per a complantar vinya una peça de terra de l'hospital, situada al territori de Barcelona, als Arenys. Hom estableix que, un cop mort Reguer, aquesta terra amb totes les millores que aquest hi hagi reverteixi a l'hospital i al seu clergue. ACB, $L A$, I, f. 285 r, doc. 760 (còpia del s. XIII).

${ }^{21} \mathrm{ACB}, L A$, I, f. 186r, d. 766 (còpia del s. XIII); I, f. 303v-304r, d. 844 (còpia del s XIII); I, f. 300 r, d. 827 (còpia del s. XIII d'una còpia anterior).

${ }^{22}$ Carme Planas, A l'entorn d'un grup eclesiàstic: els levites a Barcelona als anys $985-$ 1100, tesi de llicenciatura inèdita, Universitat de Barcelona, 1989, pp. 74-76, ha documentat un fluxe constant de donacions a la canònica de la seu al llarg de tot el segle XI.

${ }^{23} \mathrm{ACB}, L A$, I, f. 17, doc. 30; Privilegia Summum Pontificium, fol. 5r.

${ }^{24}$ Freedman posa en relació l'aparició, a finals del segle XI, dels oficis capitulars com a marca d'estatus en substitució de les velles categories clericals (diaca, subdiaca, levita) amb el fet que els capítols comencin a controlar la propietat al marge del bisbe. Paul H. FREEDMAN, The Diocese of Vic. Tradition and Regeneration in Medieval Catalonia, New Brunswick, New Jersey, Rutgers University Press, 1983, p. 48.
} 


\section{EL DOMINI CAPITULAR: CANONGES I FAMILIARS}

Sembla que entre 1111 i 1140 el bisbe Ramon i el seu successor, Oleguer, recuperaren temporalment el control del domini de la seu ${ }^{25}$.

A partir de 1140 , però, assistim a una nova onada de contractes atorgats principalment pels membres del capítol, el degà i els canonges de la seu. L'any 1144 el degà de la seu Bernat Berenguer estableix a Miró Arnau, a la seva muller Rossa i als seus fills i descendents, prop de la sagrera de Sants, una mujada "en la peça de terra que fou del feu del difunt Guillem Ramon, cap d'escola, que Bernat Berenguer, degà, té en feu per Pere, sacrista" 26 ; sembla, doncs, que el degà succeeix en la detenció d'aquest feu l'antic cap d'escola, que ja hem vist actuar en un contracte de l'any 1096.

L'expressió feu tendeix a desaparèixer quan els béns cedits procedeixen del patrimoni de la família del clergue o canonge atorgant. En alguns casos els clergues actuen com a usufructuaris de les terres que cedeixen, puix que hom preveu que, després de la seva mort, els receptors dels béns tributin les rendes a la canònica de la seu ${ }^{27}$. Aquests béns procedeixen de la dotació que acompanya l'entrada d'aquests clergues a la canònica; presuposen, per tant, una donació amb reserva d'usdefruit efectuada per l'atorgant o pels seus familiars a la institución ${ }^{28}$. D'altres vegades, són els mateixos clergues, ja vinculats a la canònica, que fan donació dels seus alous, reservant-ne l'usdefruit per a si mateixos o per a un

\footnotetext{
${ }^{25}$ Durant el seu episcopat (1116-1137), Oleguer dugué a terme una política dirigida a la recuperació de béns i rendes alienades o usurpades al domini de la seu. Cf. Gener Gonzalvo I Bou, Sant Oleguer (1060-1137). Església i poder a la Catalunya naixent, Barcelona, Rafael Dalmau, 1998, pp. 21-22.

${ }^{26} \mathrm{ACB}, L A, \mathrm{I}, \mathrm{f} .243 \mathrm{r}$, doc. 660 (còpia del s. XIII).

${ }^{27} \mathrm{~L}$ 'any 1123 el clergue Berenguer Guillem, "amb l'aprobació dels canonges de la seu", atorga a Joan Ramon i El.liarda, als seus fills i descendents, l'alou que aquests conreen, amb els casals derruïts $\mathrm{i}$ els arbres, situat a la parròquia de Santa Maria de Caldes, al lloc Rominyó. Els receptors tributaran a Berenguer Guillem, mentre visqui, i després de mort, a la canònica de la seu, 2,5 mancusades de diners, en moneda de Barcelona. ACB, $L A$, III, f. 78v, doc. 209 (còpia del s. XIII).

${ }^{28}$ L'any 1153 el canonge Pere de Ribes, amb el consentiment del bisbe Guillem i dels altres canonges, estableix a Pere Bertran i a la seva muller Maria, als seus fills i descendents, el mas Olzina, situat al terme del castell d'Olèrdola, a la parròquia de Sant Cugat de Moja, "que Arnau Pere de Ribes, pare de Pere, donà a la canònica amb el seu fill”. Els receptors lliuraran el quart de tots els fruits al canonge atorgant $\mathrm{i}$, després del seu òbit, a la canònica. $\mathrm{ACB}, L A, \mathrm{IV}, \mathrm{f}$. 114r-v, doc. 291 (còpia del s. XIII).
} 
familiar $^{29}$. L'usdefruit no implica només el benefici de les rendes sinó també la facultat de gestionar els béns, els quals resten sota el control del clergue o dels seus familiars. Les vídues poden conservar certs drets sobre les béns dels seus fills canonges, el que explica la seva intervenció en els actes de concessión ${ }^{30}$. Alguns usufructuaris laics actuen també com a gestors dels béns fins que aquests no són definitivament integrats a la canònica ${ }^{31}$.

\footnotetext{
${ }^{29}$ L'any 1126 el sacerdot Miró, clergue de l'església de Barcelona, dóna a la canònica un alou que té a Terrassa, a la parròquia de Sant Julià d'Altura, en remei de la seva ànima i dels seus pares. En reserva l'usdefruit per al seu nebot (nepos) Brunet. ACB, LA, III, f. 136r-v, d. 354 (còpia del segle XIII). L'any 1127 Pere Ramon, clergue i canonge de la séu, dóna a la canònica de Santa Creu i de Santa Eulàlia de Barcelona una peça de terra situada al costat de l'església de Santa Eulàlia del Camp, sota el camí, una altra peça de terra situada a l'Olivera Rodona, al costat del camí que porta a Sarrià, un mas, en el qual habita Guillem Morro, situat a la parròquia de Santa Eulàlia de Provençana i a Banyols, i un hort que li prengué Ramon Guillem Ferran sense dret, tal com consta en l'escriptura de compra que els seus pares feren a Olibà Guillem. Se'n reserva durant la seva vida l'usdefruit a canvi del pagament de la desena part dels esplets que surtin del mas per signacione tenedone ipsius alodii. ACB, 1-2-809 (orig.); $L A$ IV, f. 8r, doc. 23 (còpia del segle XIII). L'any 1127 el sacerdot Berenguer, clergue de l'església de Barcelona, dóna a la canònica de Barcelona l'alou propi i franc, el dret que té a les cases i l'hort que foren del seu pare, les quals té per dret hereditari, al suburbi de Barcelona, i tota la part i el dret que té en el mas de Pomar. Se'n reserva l'usdefruit vitalici a canvi del pagamet anual a la canòncia d'una lliura de cera per a il luminar el refectori. $\mathrm{ACB}, L A, \mathrm{I}, \mathrm{f}$. 43r, d. 90. (còpia del segle XIII). L'any 1127 Guillem Bremon, clergue de la seu, dóna a la canònica de Barcelona tot l'alou que té al terme de Castellbisbal, el mas anomenat Canadell, $i$ al terme del Castellvell de la Marca, al lloc que anomenen Estelella, tota l'heretat paterna que hi té, tal com consta a l'escriptura del testament del seu pare, amb la condició que mentre visqui ho tingui en benefici dels canonges $\mathrm{i}$ tributi a la canònica cada any una lliura de cera per a l'enllumenat del refectori. ACB, $L A$, IV, f. 66r-v, d. 183 (còpia del segle XIII). L'any 1135 el canonge Guillem Rotlland dóna a la canònica de la seu l'alou que té al territori de Barcelona, a la parròquia de Sant Andreu de Palomar, al lloc Vilapiscina, i l'alou que té al Vallès, a la parròquia de Sant Esteve de Vilanova, al lloc Congostell, amb el pacte que el seu germà Pere ho tingui mentre visqui $\mathrm{i}$ que després del seu òbit reverteixi en potestat de la canònica. Pere lliurarà a la canònica cada any 0,5 lliura de cera per reconeixement i per cens. $\mathrm{ACB}, L A$, II, f. 107r, d. 326 (còpia del segle XIII). L'any 1139 el prevere Ademar dóna a la canònica de la seu, el camp que anomenen Llobet, prop de la sagrera de Sants, i la tercera part de la parellada de terra que té amb el prevere Pere Bernat prop de l'Olivera Rodona, els quals té per compra. Ademar se'n reserva l'usdefruit mentre visqui a canvi del pagament anual a la canònica d'un cens d'una quartera de forment. ACB, $L A$, I, f. 159r-v, d. 418 (còpia del segle XIII). L'any 1163 el canonge Bernat de Puig Alt, dóna a la canònica de Barcelona els tres masos que té al terme del Castellvell i de Gelida i les cases i l'honor que té a Sant Joan de Samorra, els quals té per drets dels seus pares. Se'n reserva l'usdefruit vitalici a canvi del pagament anual a la canònica d'un cens d'un quarter de melle. $\mathrm{ACB}, L A$, IV, f. $81 \mathrm{r}-\mathrm{v}$, d. 217 (còpia del segle XIII).

${ }^{30}$ L'any 1145 el canonge Bernat Ros (Rubeus), amb l'aprobació de la seva mare Arsenda, estableix a Guillem Joan, la seva muller Maria i als seus fills i descendents tres peces de terra que aquests han plantat de vinya, que ell té per donació de la seva mare a la parròquia de Sant Andreu de Palomar, a ses Corts, prop de Silvià. ACB, $L A$, II, f. 65 r, doc. 183 (còpia del s. XIII).

${ }^{31}$ L'any 1140 Adelaida, vídua de Guillem Bernat Moneder, cedeix als canonges Ponç d'Orençana i Berenguer d'Arcs, i als seus, per a complantar vinya, una peça de terra que té en feu de la canònica de Barcelona, situada al damunt de l'Olivera Rodona. ACB, $L A$, I, f. 243v,
} 
Altres contractes d'aquest mateix període no fan referència als drets de la seu o de la canònica; cal suposar que els atorgants actuen a títol particular, com a gestors del seu patrimoni, tot i que no es pot excloure una omissió no innocent dels drets de la senyoria eminent ${ }^{32}$. La confusió entre el que és propi del clergue i el que és de la institució, característica del domini capitular, s'explica per la vinculació a la institució de famílies propietàries de terres per mitjà de la funció clerical d'un dels seus membres $^{33}$.

Les concessions agràries efectuades per canonges de la seu a títol privat o com a usufructuaris d'una part del domini capitular desapareixen gairebé a partir de 1157, coincidint amb la implantació del sistema de les prepositures que consagra el fraccionament del patrimoni de la canònica en dotze canongies, en endavant objecte de transmissió hereditària en mans d'un nombre limitat de famílies ${ }^{34}$. També a partir d'aquesta data es rarifiquen les concessions vitalícies que tenien com a receptors clergues i canonges de la seu, la qual cosa confirma l'estreta conexió entre usdefruit vitalici i fraccionament de la gestió del domini capitular. A partir d'aleshores aquests mateixos canonges actuen al front de les diferents prepositures de la $\mathrm{seu}^{35}$.

doc. 662 (còpia del s. XIII).

${ }^{32}$ L'any 1107 el canonge Pere Ramon cedeix a Ramon Guillem Ferran i Llambard, els seus fills i descendents, una peça de terra per a complantar vinya "que li pervingué per permuta per altres drets." ACB, $L A$, I, f. 6, doc. 9; LA, I, f. 215v, doc. 575 (còpia del s. XIII). L'any 1141 el canonge Pere Bernat estableix a Ramon Guillem i al seu fill Arnau el mas que fou de Guillem Bernat, anomenat Brocà, situat al terme del castell de Mataró, a la parròquia de Santa Maria, dins la sagrera de Mata. Els receptors seran solius de Pere Bernat, no proclamaran cap altra senyor que no sigui ell $\mathrm{i}$ el seu batlle $\mathrm{i}$ li donaran a ell $\mathrm{i}$ als seus successors un cens anual d'una perna de porc. ACB, $L A$, II, f. $124 \mathrm{v}-125 \mathrm{r}$, doc. 368 (còpia del s. XIII). El canonge Berenguer de Terrassa estableix l'any 1149 a Guiribert Guifré $\mathrm{i}$ als seus fills i descendents dos masos i un molí situats a la parròquia de Sant Pere de Terrassa, al lloc Mulnar. ACB, 1-2-956 (orig.); $L A$, III, f. $139 \mathrm{v}$, doc. 362 (còpia del s. XIII). Berenguer d'Arcs, també canonge, estableix l'any 1157 a Berenguer Poca Sang i a Vivà, als seus fills i descendents, per a plantar vinya, una peça de terra que té al territori de Barcelona, al peu de Montaguilar. $\mathrm{ACB}, L A, \mathrm{I}$. f. $120 \mathrm{v}$, doc. 302 (còpia del $\mathrm{s}$. XIII).

${ }^{33}$ Feliu, El bisbe Vives de Barcelona, pp. 179-180. Freedman, The Diocese of Vic, p. 41.

${ }^{34} \mathrm{~L}$ 'any 1157 el bisbe Guillem de Torroja i el capítol dividiren el patrimoni de la canònica en dotze prepositures, una per a cada mes, i confiaren cadascuna a un prepòsit o paborde administrador que havia de distribuir entre els canonges les porcions canonicals de la seva mesada. ACB, $L A$, I, f. 64, doc. 137 bis. Sobre l'organització i estructura interna del capítol, vegeu Àngel FÀBREGA I GRAU, La vida quotidiana a la catedral de Barcelona en declinar el Renaixement. Any 1580, Barcelona, Arxiu Capitular de la S.E. Catedral Basílica de Barcelona, 1978, pp. 30-46. (1175).

${ }^{35}$ Per ex., Berenguer de Terrassa (1163), Guillem de Rubí , prepòsit del mes de juliol 
En aquest procés, la reforma de 1157, la divisió del capítol en dotze prepositures, ha d'ésser interpretada, no com el punt de partida del sistema beneficial, sinó com la culminació d'un procés de desintegració del patrimoni (gestió i benefici) iniciat al darrer decenni del segle XI.

Tot i que no es pot parlar d'esvaniment de l'autoritat episcopal de la gestió del domini capitular, a partir de 1160 els contractes atorgats, d'acord amb la vella fòrmula, pel bisbe i pel conjunt de canonges de la seu, davallen en termes relatius en el conjunt de la documentació. En canvi, a partir de mitjan segle XII el bisbe apareix sol atorgant concessions de béns del seu patrimoni.

\section{ELS ORÍGENS DE LA MENSA EPISCOPAL}

L'existència d'un patrimoni vinculat a la funció episcopal ha d'inscriure's plenament dins del procés de desintegració del domini de la seu iniciat el decenni de 1090; pròpiament, n'és la conseqüència ${ }^{36}$. Resulta significatiu que les primeres concessions de béns del bisbat (episcopatu) apareguin a partir de 1135, quan la canònica de Barcelona ja funciona autònomament. L'any 1137 l'arquebisbe Oleguer, com a bisbe de Barcelona, i el convent de canonges de la seu cedeixen al diaca Hugó el mas de Lledó de Mollet, que pervingué a Oleguer "per dret del bisbat de la seu de Barcelona" 37 . L'any 1139 el bisbe Arnau i els canonges de la seu cedeixen a Berenguer Ramon i Ermessenda, als seus fills i descendents, per a complantar vinya, una peça de terra "que és de dret del bisbe", situada al territori de Barcelona, al damunt del Cogoll ${ }^{38}$. En les cessions posteriors a 1145 els canonges de la seu desapareixen de la formula típica que encapçala les cessions del patrimoni de la catedral; el bisbe figura sòl atorgant les terres de la porció del domini de la seu que a partir d'aleshores

\footnotetext{
${ }^{36} \mathrm{La}$ separació dels patrimonis del bisbe i del capítol de la catedral fou un fenomen general a totes les diòcesis. A Vic, es produí a finals del segle XI. FrEEDMAN, The Diocese of Vic, $\mathrm{p}$. 48. A Avila la separació dels béns i de les jurisdiccions del capítol i del bisbe s'hauria produït poc abans de 1171. Cf. Ángel BARRIOS GARCÍA, Estructuras agrarias y de poder en Castilla El ejemplo de Avila (1085-1320), Salamanca, Ediciones Universidad de Salamanca-Institución Gran duque de Alba, 1984, I, p. 259.

${ }^{37} \mathrm{ACB}, L A$, IV , f. 196r, doc. 452 (còpia del s. XIII).

${ }^{38} \mathrm{ACB}, L A, \mathrm{I}$, f. $138 \mathrm{v}-139 \mathrm{r}$, doc. 357 (còpia del s. XIII).
} 
resta vinculat al seu càrrec ${ }^{39}$. L'any 1150 el bisbe Guillem cedeix a Dalmau Amat per a conrear mentre visqui el mas de Provençals amb les seves terres. El mas afronta a migdia amb l'alou del bisbe i a tramuntana amb l'alou de la canònica ${ }^{40}$. Fites claus en el procés de definició del temporal del bisbe de Barcelona, separat dels de la canònica i de la resta d'institucions vinculades a la seu, són els privilegis d'Alexandre III dels anys 1169 i 1176 que estableixen els límits de la diòcesi de Barcelona i relacionen les possessions del que en endavant constituiran la mensa episcopal ${ }^{41}$.

La constitució d'un patrimoni propi de l'ardiaca, la segona funció eclesiàstica més important de la diòcesi, s'hauria produït per les mateixes dates. La primera concessió eféctuada per l'ardiaca de la seu data de $1127^{42}$; sembla, però, que en -aquesta ocasió Pere actua en substitució del bisbe al front del domini capitular ${ }^{43}$. En canvi, l'any 1134 el mateix ardiaca cedeix al prevere Ademar i al seu "nodrit" Cuc unes cases situades a la sagrera de Sant Julià de Montjuïc i, prop d'elles, una vinya, un hort i unes oliveres, que li pervingueren "pel feu de l'ardiaconat" ${ }^{44}$. Notem la proximitat d'aquests béns a l'alou de ipso Circulo que l'any 1078 l'ardiaca Bernat Guillem havia rebut en usdefruit vitalici del bisbe Umbert ${ }^{45}$. Els anys 1143 i 1144 l'ardiaca Pere cedeix la parellada de l'ardiaconat situada a Granollers, sota les cases de Sant Miquel; en aquestes dues concessions l'expressió "feu" ha desaparegut ${ }^{46}$.

${ }^{39} 1145$ : "Guillem, bisbe de Barcelona, amb el consentiment de Berenguer, germà de Guillem de Terrassa, dóna a Guillem de Terrassa..." ACA, Monacals, Montalegre, perg. 103.

${ }^{40} \mathrm{ACB}, L A$, II, f. $121 \mathrm{v}-122 \mathrm{r}$, doc. 362.

${ }^{41} \mathrm{ADB}$, Mensa Episcopal, títol II, núm. 2, D i E; ACB, LA, I, f. 20, doc. 32 i 33 (còpies del s. XIII). Transcripció: Maria PARDo I SABARTÉs, Mensa episcopal de Barcelona (878-1299), Barcelona, Fundació Noguera, 1994, pp. 59-62.

${ }^{42}$ Deixem de banda les concessions de 1061 i 1068, en les quals actua al costat del bisbe.

${ }^{43}$ Pere, ardiaca, i els altres clergues de la seu cedeixen als germans Ramon Pere i Pere de Far i a un fill o parent d'ells l'alou que fou de Bernat Ermengol. Hom estipula la reversió de l'alou a la canònica de la seu després de la mort dels receptors. ACB, $L A$, III, f. $55 \mathrm{v}$, doc. 160 (còpia del s. XIII).

${ }^{44} \mathrm{ACB}, L A, \mathrm{I}$, f. $297 \mathrm{v}$, doc. 817 (còpia del s. XIII)

${ }^{45} \mathrm{ACB}, L A$, IV, f. $14 \mathrm{r}$, doc. 43 (còpia del s. XIII). XIII).

${ }^{46} \mathrm{ACB}, L A, \mathrm{I}$, f. 38r, doc. 108 (còpia del s. XIII); LA, III, f. 38r-v, doc. 109 (còpia del s. 


\section{LA HIPÒTESI D'UNA CRISI DEL DOMINI}

La disgregació del patrimoni de la seu de Barcelona i la privatització de la gestió i del benefici de porcions importants del domini ha de relacionar-se amb la crisi que afectà Barcelona i el seu hinterland entre $1090 \mathrm{i}$ $1110^{47}$. Sembla existir una estreta relació entre els orígens de la crisi, marcats per les fams de $1092-1094^{48}$ i la primera onada de feus eclesiàstics, entre 1094 i 1098.

La crisi del període 1090-1110 degué provocar una forta davallada de les rendes de la seu de Barcelona, que en bona mesura es basaven en els rendiments de la viticultura periurbana, i obligà a una reorientació de les inversions $\mathrm{i}$ de la producció ${ }^{49}$. En aquest context, alguns eclesiàstics vinculats a la seu haurien aprofitat les dificultats de la institució per a privatitzar porcions importants de les rendes del seu domini. Essent la propietat eclesiàstica inalienable, la fòrmula jurídica utilitzada fou el feu eclesiàstic: hom cedia l'usdefruit, la gestió $\mathrm{i}$ el benefici, d'uns béns a canvi d'un pagament fix anual i d'una forta entrada de diner. El feu eclesiàstic pogué tenir, d'aquesta manera, una funció creditícia ${ }^{50}$.

Si durant les :ams de 1092-1094 i en caresties posteriors alguns eclesiàstics aprofitaren les dificultats dels habitants de la ciutat per a adquirir

\footnotetext{
${ }^{47}$ Sobre la crisi del període 1190-1140, vegeu Stephen P. BENSCH, Barcelona and its rulers, 1096-1291, Cambridge, Cambridge University Press, 1995, pp. 85-121.

${ }^{48} \mathrm{La}$ concentració de vendes motivades per necessitat de queviures indiquen que una situació greu de carestia afectà la ciutat de Barcelona i al seu entorn rural els hiverns de 1092, 1093 i 1094. La fam de 1092-1094 deixà una petjada profunda en la memòria dels habitants de la ciutat. L'any 1116 Salomon Eriman i la seva muller Maria heretaren al seu fill Guifré el casal noble, "amb escala de pedra", que tenien a Barcelona, als Arcs, prop del Palau Comtal menor. Ho feren "propter multis beneficiis et serviciis quem nobis fecistis et facis et in antea feceris et quod cunctum tuum avere quod umquam potuisti abere totum in nobis expendisti per plurimas fames qui fuerunt in patria Barchinone ubi non fuit qui succurrisset nobis nec valuisset nullus nisi Deus et tu, filium nostrum”. ACA, Cancelleria, Ramon Berenguer III, perg. 191.

${ }^{49}$ És paradigmàtic l'exemple de Ricard Guillem, que entre 1065 i 1081 efectua compres, principalment de terres destinades a la plantació de vinya, per un valor aproximat de 10.000 mancusos d'or; posteriorment abandonarà bruscament aquesta activitat $i$ invertirà en l'adquisició de feus. José Enrique RUIZ DOMÉNEC, El origen del capital comercial en Barcelona, “Miscellanea Barcinonensia”, XXXI (abril 1972), pp. 55-88

${ }^{50} \mathrm{~A}$ Avila, Angel Barrios senyala la tendència a la laicalització dels membres del capítol i a la participació d'alguns laics en beneficis materials, derivats de l'assignació de préstecs eclesiàstics. Cf. Angel BARRIOS:GARCía, Estructuras agrarias y de poder en Castilla. El ejemplo de Ávila (1085-1320), I, p. 259.
} 
a la baixa la propietat dels seus immobles o de les seves terres ${ }^{51}$, per què no pensar que actuarien amb reflexos similars en relació a la institució eclesiàstica a la qual servien? Algunes concessions vitalícies efectuades a clergues i canonges de la seu contra el pagament de sumes respectables de numerari evoquen operacions creditícies de gran volada. L'any 1098, en plena crisi, el prepòsit de la seu, amb el consentiment del bisbe Folc i dels canonges, cedí al clergue Miró Balloví de la canònica l'usdefruit vitalici del mas i de les terres i vinyes que la canònica tenia a la parròquia de Sant Andreu de Palomar, a Romanet i a la platja de llevant, que havia tingut Miró Goltred, i les cases que foren del clergue Company Tudisc. Miró Balloví, que durant la resta de la seva vida hauria de satisfer pagar a la canònica un cens anual d'un sou, desemborsà per aquesta concessió la suma de 56 mancusos d'or de València ${ }^{52}$.

En alguns casos, els clergues es comprometien a invertir en les mateixes terres que rebien en benefici; indirectament contribuien a rendibilitzar les explotacions. A partir del tercer decenni del segle XII alguns clergues reberen de mans de l'ardiaca o del bisbe porcions del domini de la seu amb la missió de restaurar-ne els masos, construir-hi torres i posar en explotació les terres. A canvi del benefici, del dret a percebre'n les rendes, el clergue restava constret a un pagament fix anual a la institució. Òbviament, el benefici de les terres era la contrapartida de les inversions que el clergue es comprometia a efectuar-hi ${ }^{53}$.

\footnotetext{
${ }^{51}$ El 22 de desembre de 1092 la femina Petronila, tement per la vida dels seus fills petits i per la seva pròpia per manca de queviures, vengué al clergue Ramon Lleopard i a Bernat Otger tres quartes parts de la casa que fou de Ponç Duran i del seu germà Guitard, situada al costat de la muralla de llevant de Barcelona, pel preu de 25 mancusos de València. ACB, 1-4-311. A Barcelona, l'l de març de 1094 Geribert Bonfill i la seva muller, la femina Nèvia, vengueren al clergue Ardenci dues parts l'alou que tenen al Clot de la Mel, prop de Parets Antigues, pel preu de 74,5 mancusos d'or de València. Ho feren, moguts per la necessitat, "per poder viure ells i els seus fills." ACB, LA, I, f. 185v, d. 496 (còpia del s. XIII). El 19 de maig els germans Onofred Bernat, Guifré Bernat $\mathrm{i}$ Domènec Bernat vengueren al clergue Pere Umbert diverses peces de vinya que tenen a Esplugues pel preu de 30 mancusos d'or de València de rovalls. ACB, LA, IV, f. 42v, d. 121 (còpia del s. XIII).

${ }^{52} \mathrm{ACB}, 1-1-313$; LA, II, f. 55v-56r, doc. 151 (còpia del s. XIII).

${ }^{53}$ Exemple d'aquests clergues emprenedors que entren en una relació contractual amb la seu de Barcelona és Ademar que l'any 1134 rep de l'ardiaca de la seu una casa amb vinya, hort oliveres i arbres davant les portes de l'església de Sant Julià de Montjuïc, amb la missió d'edificar-ho i millorar-ho. Pagarà cada any a la seu 1 morabatí, i el 1134 rep de l'arquebisbe Oleguer i dels canonges d ela seu el mas de Torre Esllampegada situtat a Banyols, amb la missió de construir-hi una torre de pedra i calç, a canvi del pagament de dos porcs canonicals. ACB, LA, I, f. 297v, d. 817 (còpia del segle XIII); LA, IV, f. Iv, d. 3 (idem).
} 
Segons la hipòtesi que defensem, l'esclat de la gestió del domini de la seu i l'aparició de feus eclesiàstics que prefiguraven el sistema beneficial ha de posar-se en relació, primer, amb una estagnació o davallada de les rendes $\mathrm{i}$, en segon lloc, amb el paper que, en aquest context, un cercle reduït d'eclesiàstics vinculats a famílies amb una forta implantació econòmica al territori periurbà jugaren prop de l'església de Barcelona.

Tot i la recuperació econòmica del període 1111-1140, no sembla que les rendes de la seu augmentessin substancialment. El numerus clausus de quartanta canongies que fixava la butlla papal de confirmació de béns atorgada al capítol barceloní l'any 1104 no experimentà modificacions al llarg del segle $\mathrm{XII}^{54}$, tot i que a la pràctica el nombre de canonges de la seu pogué ésser més nombrós. Les reformes posteriors que cercaven redotar el temporal de la seu no pogueren augmentar el grup eclesiàstic beneficiari.

L'estagnació de les rendes del capítol permetria explicar que el desenvolupament del sistema beneficial en el si de la canònica no s'aturés, sinó que, ben al contrari, reprengués amb força a partir de 1135. A partir d'aquesta data, un cercle d'eclesiàstics procedents de famílies amb interessos en l'economia periurbana intervingueren activament en la redotació del temporal de la canònica. En aquesta segona fase la privatització dels beneficis de capítol s'efectuà mitjançant l'accés a les canongies que comportava importants oblacions de béns que acompanyaven l'entrada dels canonges oblats a la catedral ${ }^{55}$. Aquests béns romanien sovint sota control de la família del clergue, oscil-lant en una situació ambigua entre el patrimoni de la canònica i el del clergue. Afirma Viader que "existí en la comunitat de canonges i l'entorn del capítol, una clientela que, al segle XI i a començaments del XII, utilitzà els seus lligams familiars per explotar les terres de la catedral" $"$. La proposició es podria formular també de la manera següent: un cercle estret de famílies haurien aprofitat la vinculació dels seus membres al capítol per a "explotar" les terres de la catedral. Clergues i familiars haurien sostret del control episcopal la gestió i el benefici d'una part significativa, possiblement la més rendible, del patrimoni de la seu.

\footnotetext{
${ }^{54} \mathrm{El}$ privilegi atorgat pel papa Alexandre III l'any 1176 fixava el mateix nombre de canongies. PARDO, Mensa episcopal, pp. 59-62.

${ }^{55}$ Sobre l'oblació d'infants, vegeu Joseph LYNCH, Simoniacal Entry into Religious Life from 1000 to 1260, Columbus, 1976, pp. 36-50.

${ }^{56}$ VIADER, Autour d'une pratique juridique, p. 152.
} 
Cap al 1135-1140 el bisbe, o el seu representant, l'ardiaca de la seu, com a gestor suprem dels patrimoni de l'església de Barcelona, hauria esdevingut una figura teòrica, situada al front d'una unitat en bona mesura fictícia. En aquest moment sorgí el concepte d'un patrimoni vinculat a la figura i a la funció del bisbe i de l'ardiaca; la part més rendible del patrimoni de la seu, el territori periurbà, n'havia estat sostret. El renaixement del poder episcopal a partir del darrer quart del segle XII havia de produir-se sobre noves bases.

\section{RÉSUMÉ}

Entre 1090 et 1157, date de l'instauration du système des prevôtés dans le chapitre de la cathédrale de Barcelone, deux changements importants marquent un tournant dans l'histoire de cette institution: d'un côté, l'éclatement du domaine (gestion et bénéfice), avec la parution et diffusion des "fiefs" ecclésiastiques; de l'autre, la formation de patrimoines indépendants rattachés au chapitre de chanoines et aux figures de l'evêque et de l'archidiacre. Cet article offre une première approche à l'histoire de ces deux processus étroitement liés.

\section{SUMMARY}

Between 1090 and 1157, the date of the introduction of a system of provostships, two important changes signal a turning point in the history of the cathedral chapter of Barcelona: on the one hand, the breakup of integral administration of the demesne, with the appearance and spread of ecclesiastical "fiefs" (later benefices); on the other, the formation of independent patrimonies linked to the chapter of canons and to the bishop and archdeacon. This article offers a sketch of the history and the causes of these two closely interrelated developments. 